\title{
Induction of Apoptosis by Citri Pericarpium Methanol Extract through Reactive Oxygen Species Generation in U937 Human Leukemia Cells
}

\author{
Ga Hee Kim ${ }^{1}$, Moon Hee Lee ${ }^{1,2}$, Min Ho Han ${ }^{1,2}$, Cheol Park ${ }^{3}$, Su Hyun Hong ${ }^{1 *}$ and Yung Hyun Choi ${ }^{1,2 *}$ \\ ${ }^{1}$ Department of Biochemistry, Dongeui University College of Oriental Medicine, Busan 614-052, Korea \\ ${ }^{2}$ Anti-Aging Research Center and Blue-Bio Industry RIC, Dongeui University, Busan 614714, Korea \\ ${ }^{3}$ Department of Molecular Biology, College of Natural Sciences, , Dongeui University, Busan 614-714, Korea
}

Received August 22, 2013 /Revised August 25, 2013 /Accepted August 28, 2013

\begin{abstract}
Citri Pericarpium is one of the most commonly used traditional herbal medicines in Korea, China, and Japan. Its extracts have many properties including the treatment of indigestion and inflammatory respiratory syndromes such as bronchitis and asthma. However, the underlying molecular mechanisms of anti-cancer activity and molecular targets are not fully understood. In this work, we investigated the anti-proliferative activity of Citri Pericapium (EMCP) methanol extract on reactive oxygen species (ROS) production and the association of these effects with apoptotic cell death using U937 human leukemia cells in vitro. EMCP treatment decreased cell proliferation in a dose-dependent manner following an increase of the sub-G1 phase, the down-regulation of Bax proteins, the activation of caspases, the degradation of poly (ADP-ribose) polymerase proteins (PARP), and the induction of ROS generation. However, the quenching of ROS generation by $\mathrm{N}$-acetyl-L-cysteine administration, a scavenger of ROS, reversed the EMCP-induced apoptosis effects. In addition, heme oxygenase-1 expression also recovered by inhibiting the nuclear translocation of phosphorylated NF-E2-related factor 2. Taken together, our data indicate that ROS are involved as key mediators in the early molecular events in the EMCP-induced apoptotic pathway.
\end{abstract}

Key words : Citri Pericapium, apoptosis, reactive oxygen species, heme oxygenase-1, NF-E2-related factor 2

\section{서 론}

진피(陳皮, Citri Pericarpium)는 운향과(Rutaceae)에 속한 상록 소교목인 귤나무(Citrus unshiu Markovich) 및 같은 속 근연 식물의 성숙한 과실의 열매껍질을 건조한 것으로 한국, 중국 및 일본에서 전통적으로 가장 많이 쓰이는 약재 중 하나 이다 $[13,17]$. 동의보감에는 '가슴에 기가 뭉친 것을 풀리게 하 고, 입맛을 당기게 하며, 소화를 잘 시키고 이질을 멎게 해준 다. 구역질을 그치게 하며, 대소변을 잘 보게 한다. 또한 가래 를 삭히고 기침을 낫게 한다'고 진피의 효능을 기재하고 있다 [8]. 진피에 관한 실험적 연구 결과로는 진피에 함유된 alkaloid 성분의 천식 완화 기능[16], 고지혈증 흰쥐의 지질 저하 효과[19], 진피 에탄올 추출물의 콜라겐 유도 관절염 마우스에 서 관절염 개선 효과[8] 및 진피 에탄올 추출물의 HIT-T15 세

*Corresponding author

Tel : +82-51-850-8664, Fax : +82-51-853-4036

E-mail : hongsh@deu.ac.kr

Tel : +82-51-850-7431, Fax : +82-51-853-4036

E-mail : choiyh@deu.ac.kr

This is an Open-Access article distributed under the terms of the Creative Commons Attribution Non-Commercial License (http://creativecommons.org/licenses/by-nc/3.0) which permits unrestricted non-commercial use, distribution, and reproduction in any medium, provided the original work is properly cited
포의 산화적 손상 억제 효과[7] 등이 보고되어 있으나 암세포 성장 억제나 그 기전에 대한 연구는 미흡한 실정이다.

최근 효과적인 항암예방과 치료를 위하여 세포사멸 (apoptosis) 과정을 통하여 비정상적인 세포나 암세포를 제거 하는 치료제의 개발이 중요시되고 있다. 특히 apoptosis는 세 포질 및 염색질의 응축, 세포 표면에 phosphatidylserine의 과 발현, DNA 단편화 및 세포자멸사체 형성 등과 같은 형태적 또는 생화학적인 변화를 동반하며, 만약 이러한 과정이 실패 하게 되면 암 및 퇴행성질환을 포함한 여러 가지 질병의 원인 이 되며, 특히 apoptosis는 암화 과정의 여러 단계에서 암세포 의 증식 억제를 위한 중요한 표적이 되고 있다 $[2,3]$. Apoptosis 조절 기전에 apoptosis의 유도와 억제를 동시에 조절하는 인 자들로 구성되어있는 Bcl-2 family 단백질의 발현 변화가 중요 한 역할을 하는 경우가 많다[20]. 또한, caspases는 다양한 자극 에 발현이 증가하거나 활성화되어 암세포의 apoptosis를 유발 시키는 중요한 역할을 하는 것으로 알려져 있어, 항암 치료의 표적 유전자로 주목을 받고 있다[4]. 이들은 정상적으로 증식 중인 세포에서는 pro-enzyme 형태로 존재하고 있다가, apoptosis 유도신호에 의해 활성화되어 직접 또는 간접적으로 세포 내 존재하는 poly (ADP-ribose) polymerase (PARP) 등과 같 은 많은 표적 단백질의 분해에 관여한다고 알려져 있다[18]. 최근 연구에 의하면 짝을 이루지 않는 전자를 보유한 산소 
를 가지고 있어 반응성이 매우 높은 활성산소종(reactive oxygen species, ROS)의 생성이 apoptosis의 유도에 큰 영향을 미치는 것으로 보고되었다[1]. 세포 내 ROS의 발생이 많아지 면 heme oxygenase-1 (HO-1)의 발현이 유도되어 이를 조절하 는 기능을 한다. HO-1의 발현은 주로 전사인자인 NF-E2-related factor 2 (Nrf2)에 의해 조절되는데, 인산화된 Nrf2가 핵으로 이동하여 $\mathrm{NAD}(\mathrm{P}) \mathrm{H}$, quinine oxidoreductase-1, glutatione Stransferase, glutamate- cysteine ligase 및 HO-1과 같은 2단계 항산화 효소들의 활성을 조절한다[10, 11].

본 실험에서는 진피 추출물의 항암활성 기전을 조사하기 위하여 인체 백혈병세포인 U937 세포를 대상으로 진피 메탄 올 추출물(methanol extract of Citri Pericarpium, MECP)의 암세포 성장억제 효과, apoptosis 유발에 미치는 영향을 조사 하였으며, 이러한 과정에 ROS의 발생과 이와 관련되어 있는 유전자의 발현 조절이 중요한 인자로 작용하고 있음을 제시하 였다.

\section{재료 및 방법}

\section{시료준비}

본 연구에 사용된 진피는 대한생약(주(부산, 한국)에서 구입 하여 흐르는 물에 수회 세척하고 그늘에서 하루 동안 건조시 켜 사용하였다. $\mathrm{MECP}$ 를 얻기 위하여 건조된 진피 $200 \mathrm{~g}$ 에 메탄올을 1.51 첨가하여 $100 \mathrm{rpm}, 35^{\circ} \mathrm{C}$ 조건에서 5 일간 교반 하였다. 그 후 상층액만 분리하여 건조하고, 분말을 200 $\mathrm{mg} / \mathrm{ml}$ 농도로 dimethylsulfoxide (DMSO, Sigma-Aldrich)에 용해시킨 후 이를 적정 농도로 배지에 희석하여 처리하였다.

\section{세포배양}

실험에 사용한 인체 백혈병 세포(U937)는 생명공학연구소 (KRIBB, 대전, 한국)에서 분양 받았으며, 암세포의 배양을 위 해 RPMI-1640 배지(Gibco BRL, Grand Island, NY, USA)와 $10 \%$ 의 우태아혈청(fetal bovine serum, FBS, Gibco BRL) 및 $1 \%$ 의 penicillin이 포함된 성장배지를 사용하였으며, $37^{\circ} \mathrm{C}, 5 \%$ $\mathrm{CO}_{2}$ 조건 하에서 배양하였다. 세포수의 증식에 따른 과밀도 현상과 적정수의 세포를 유지하기 위하여 성장배지의 교환을 매 24 시간마다 실시하였다.

\section{MTT assay를 이용한 세포 생존율의 측정}

세포 배양용 6 well plate에 $3 \times 10^{5}$ 개/ml로 세포를 분주하고 $100 \mu \mathrm{g} / \mathrm{ml}$ 의 EMCP를 각 well 당 적정 농도로 처리하였다. 24 시간 후 배지를 제거하고 tetrazolium bromide salt (MTT, Ameresco, Solon, Ohio, USA)를 $0.5 \mathrm{mg} / \mathrm{ml}$ 농도로 희석하여 $200 \mu \mathrm{l}$ 씩 분주하고 $37^{\circ} \mathrm{C}$ 에서 2 시간 동안 다시 배양하였다. 배양이 끝난 다음 MTT 시약을 제거하고 DMSO를 $1 \mathrm{ml}$ 씩 각 well에 분주하여 생성된 formazan을 모두 녹인 후 96 well plate에 $200 \mu 1$ 씩 옮겨서 ELISA reader (Molecular Devices, Sunnyvale, CA, USA)로 $540 \mathrm{~nm}$ 에서 흡광도를 측정하였다.

\section{DAPI staining에 의한 세포핵의 형태 관찰}

Apoptosis가 유발되었을 경우 특이적으로 나타나는 핵의 형태적 변화를 관찰하기 위하여 $\mathrm{EMCP}$ 가 처리된 세포를 모은 다음 2,000 rpm으로 5 분간 원심 분리하여 상층액을 제거하고 $37 \%$ formaldehyde 용액과 PBS를 1:9의 비율로 섞은 fixing solution을 모아진 세포에 $500 \mu \mathrm{l}$ 첨가하여 충분히 섞은 후, 상온에서 10 분 동안 고정하였다. 고정된 세포를 $2,000 \mathrm{rpm}$ 으 로 5 분간 원심 분리하여 fixing solution을 제거하고 PBS 200 $\mu \mathrm{l}$ 에 부유시킨 후 세포가 포함되어 있는 PBS $80 \mu \mathrm{l}$ 를 slide glass 위에 떨어뜨리고 $1,000 \mathrm{rpm}$ 에서 5 분간 cytospin하여 세포를 slide glass에 부착하였다. 세포가 부착된 slide glass를 $\mathrm{PBS}$ 로 2 3 회 정도 세척하고 $\mathrm{PBS}$ 가 마르기 전에 $0.2 \%$ 의 Triton X-100 (Amresco, Solon, OH, USA)를 첨가하여 상온에 서 10 분간 고정한 후 $2.5 \mathrm{\mu g} / \mathrm{ml}$ 농도의 $4^{\prime}, 6$-diamidino-2-phenylindole (DAPI, Sigma-Aldrich) 용액을 처리 하여 상온에서 15 분간 염색하였다. 염색이 끝난 후 DAPI 용 액을 충분하게 세척하고 mounting solution을 처리한 후 형광 현미경을 이용하여 400 배의 배율로 각 농도에 따른 암세포의 핵의 형태 변화를 관찰한 다음 Axio Vision 프로그램을 이용 하여 사진 촬영을 하였다.

\section{Flow cytometry 분석}

$\mathrm{U} 937$ 세포에서 $\mathrm{EMCP}$ 가 유발하는 apoptosis 정도를 정량 적으로 분석하기 위하여 정상 및 $\mathrm{EMCP}$ 가 24 시간 동안 처리 된 세포들을 모은 다음 2,000 rpm으로 5 분간 원심분리하여 상층액을 제거한 후 $\mathrm{PBS}$ 를 이용하여 2 3회 정도 세척하였다. 준비된 세포는 Cycle TEST PLUS DNA REAGENT Kit (Becton Dickinson, San Jose, CA, USA)를 이용하여 고정 및 염색을 하여 $4^{\circ} \mathrm{C}$, 암실에서 30 분 동안 반응을 시켰다. 반응시 킨 세포를 35-mm mesh를 이용하여 단일세포로 분리한 후 FACS Calibur (Becton Dickinson)를 적용시켜 형광반응에 따 른 Cellular DNA content 및 histogram을 CellQuest software 및 ModiFit LT (Becton Dickinson) 프로그램을 이용하여 분석 하였다.

\section{$\mathrm{ROS}$ 생성 변화 측정}

$\mathrm{ROS}$ 의 양적 변화를 확인하기 위하여 준비된 세포들을 fluorescent probe 인 2 $7^{\prime}$-di-chlorodihydrofluorescein diacetate ( $\mathrm{H}_{2} \mathrm{DCFDA}$, Molecular Probes, Leiden, Netherlands) $10 \mu \mathrm{M}$ 로 20 분간 염색 후 DNA flow cytometer를 사용하여 분석을 하였다. ROS 억제를 위한 ROS scavenger인 N-ace-tylcysteine (NAC, Sigma-Aldrich) 처리는 EMCP을 처리하기 1 시간 전처 리하였다. 


\section{Western blot analysis에 의한 단백질 발현의 분석}

준비된 세포들을 모은 다음 적당량의 lysis buffer $[25 \mathrm{mM}$ Tris-Cl (pH 7.5), $250 \mathrm{mM} \mathrm{NaCl}, 5 \mathrm{mM}$ EDTA, 1\% NP-40, $1 \mathrm{mM}$ pheny- methylsulfonyl fluoride (PMSF), $5 \mathrm{mM}$ dithiothreitol (DTT)]를 첨가하여 $4^{\circ} \mathrm{C}$ 에서 1 시간 동안 반응시킨 후, $14,000 \mathrm{rpm}$ 으로 30 분간 원심분리하여 상층액에 있는 total 단백질을 분리하였다. 상층액의 단백질 농도는 Bio-Rad 단백 질 정량 시약(Bio-Rad, Herculs, CA, USA)을 이용하여 정량 한 다음 동량의 Laemilni sample buffer (Bio-Rad)를 섞어서 protein sample을 만들었다. 정량한 후, 동일한 양의 단백질을 sodium dodecyl sulphate (SDS)-polyacrylamide gel을 이용 하여 전기영동으로 분리한 후, nitrocellulose membrane (Schleicher and Schuell, Keene, NH, USA)으로 electroblotting에 의해 전이시켰다. 분리된 단백질이 전이된 nitrocellulose membrane을 5\% skim milk를 1 시간 처리하여 비특 이적인 단백질들에 대한 blocking을 실시하고 1 차 antibody 를 처리하여 상온에서 2 시간 이상 또는 $4^{\circ} \mathrm{C}$ 에서 over night 시킨 다음 PBS-T로 세척(10 분간 3번)하고 처리된 1차 antibody에 맞는 2차 antibody (PBS-T로 1:1,500으로 희석하여 사 용)를 사용하여 상온에서 1 시간 정도 반응시켰다. 반응이 끝 난 후 암실에서 Enhanced Chemiluminoesence solution (Amersham Life Science Corp., Arlington Heights, IL, USA) 을 적용시킨 다음 X-ray film에 감광시켜 특정 단백질의 발현 양을 분석하였다.

\section{핵 및 세포질 단백질의 분리}

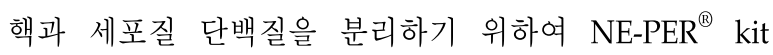
(PIERCE, Rockford, IL, USA)를 사용하였으며, 준비된 적정량 의 세포에 cytosolic extraction reagent (CER) I 을 처리하고 약 15 초간 부유시킨 후 10 분간 $4^{\circ} \mathrm{C}$ 에 보관했다. 다시 적정량 의 CER II를 넣은 뒤 10 초간 부유시킨 후, $14,000 \mathrm{rpm}$ 에서 10 분간 원심분리를 한 뒤 세포질인 부유층을 제거하였다. 분 리된 핵들에 nuclear extraction reagent를 혼합하여 15 초간 부유시킨 후 10 분간 $4^{\circ} \mathrm{C}$ 에 보관하는 과정을 총 3 회 반복했다. 최종적으로 $16,000 \mathrm{rpm}$ 에서 10 분간 원심분리를 시행하여 핵 의 단백질로 이루어진 상층액을 얻어냈다. 분리된 상층액에서 단백질을 정량법에 의해 정량하였다.

\section{통계 처리}

모든 실험결과는 평균값으로 표시하였고 SigmaPlot을 이용 하여 Student $t$-test를 이용하여 통계적 유의성을 얻었다.

\section{결과 및 고찰}

\section{$\mathrm{EMCP}$ 가 U937 세포의 증식에 미치는 영향}

$\mathrm{EMCP}$ 의 처리에 따른 U937 세포의 성장억제 정도를 알아

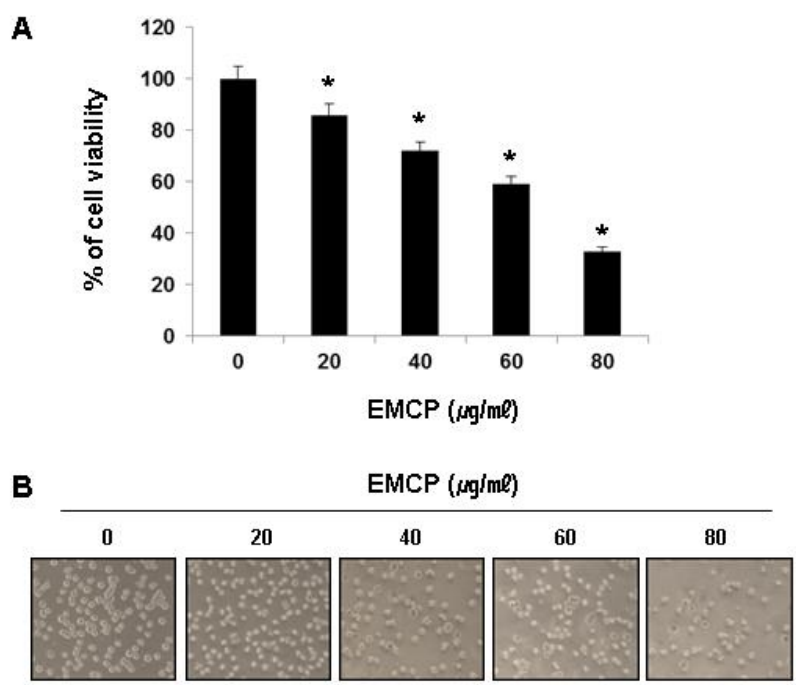

Fig. 1. EMCP inhibited cell proliferation in a dose-dependent manner in U937 human leukemia cells. (A) U937 cells were seeded at $3 \times 10^{5}$ cells per well in a 6 -well plate. Cells were treated with diverse concentration of EMCP for $24 \mathrm{~h}$ and MTT assay was performed. The significance was determined by a Student's t-test ${ }^{*} p<0.05$, compared with control). (B) Cells were visualized by an inverted light microscope (Magnification, $\times 200$ ).

보기 위하여 적정 농도의 $\mathrm{EMCP}$ 를 24 시간 동안 처리한 후 MTT assay를 실시하였으며, Fig. 1A에 나타낸 바와 같이 $\mathrm{EMCP}$ 처리 농도 의존적으로 U937의 세포 증식이 억제되었음 을 확인하였다. 동일 조건에서 U937 세포의 전체적인 형태변 화를 관찰한 결과, $\mathrm{EMCP}$ 처리농도가 증가할수록 전체적인 세포의 밀도가 유의적으로 감소함을 알 수 있었으며(Fig. 1B), membrane blebbing 현상과 같은 apoptosis 유발 시 특이하게 관찰되는 형태적 변형[14]이 관찰되었다. 이러한 결과를 바탕 으로 $\mathrm{EMCP}$ 에 의한 U937 세포 증식억제가 apoptosis의 유발 과 관계가 있을 것으로 예상되어 추후 실험을 진행하였다.

\section{EMCP 처리에 의한 apoptosis의 유발}

$\mathrm{EMCP}$ 의 처리에 의한 U937 세포의 증식 억제가 apoptosis 유발과 관련성이 있는지의 여부를 조사하기 위하여 핵의 형태 적 변화와 flow cytometry 분석을 실시하였다. 우선 apoptosis 의 직접적인 증거를 제시하기 위하여 정상 및 $\mathrm{EMCP}$ 가 처리된 배지에서 24 시간 동안 배양한 U937 세포를 대상으로 핵산에 특이적으로 결합하는 DAPI 염색을 통하여 핵의 형태학적 변 화를 관찰하였다. Fig. $2 \mathrm{~A}$ 의 결과에서 알 수 있듯이 정상 조건 에서 배양된 세포와는 다르게 $\mathrm{EMCP}$ 가 처리된 배지에서 배양 된 세포에서는 apoptosis가 일어난 세포에서 전형적으로 관찰 되는 DNA 단편화에 의한 apoptotic body의 형성[5]이 처리 농도의존적으로 증가되었음을 확인하였다. 다음은 propidium iodide (PI) 염색을 통한 세포주기 빈도 변화를 조사하였 


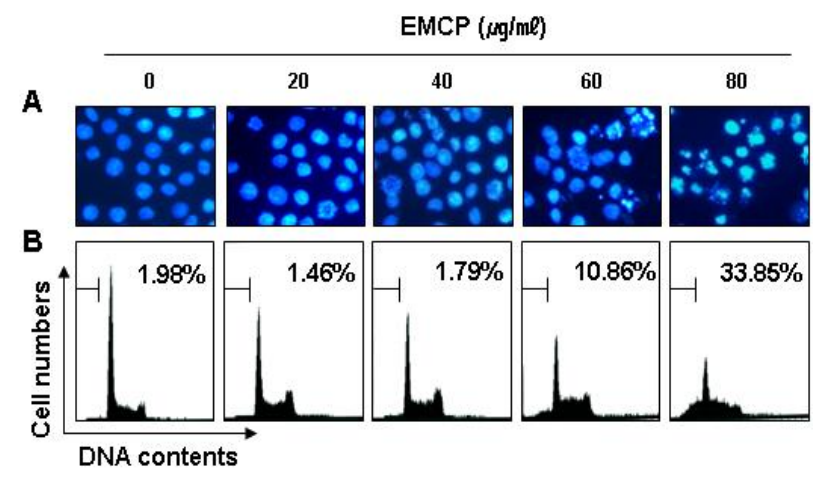

Fig. 2. EMCP stimulation increased percentage of sub-G1 population and caused apoptotic morphological changes in U937 cells. (A) After treatment with EMCP for $24 \mathrm{~h}$, the cells were stained with DAPI solution. Stained nuclei were then observed under a fluorescent microscope using a blue filter (magnification, $\times 400$ ). (B) The cells were stained with PI for flow cytometry. The percentage of the sub-G1 fraction is presented. The data represent the average of two independent experiments.

으며, Fig. 2B에 나타낸 바와 같이 apoptosis 유발 집단에 해당 하는 sub-G1기의 세포 빈도가 $\mathrm{EMCP}$ 처리 농도 의존적으로 유의적으로 증가하였음을 알 수 있었다. 따라서 $\mathrm{EMCP}$ 처리에 의한 인체 백혈병세포의 증식억제는 apoptosis과 직접적인 연 관성이 있음을 알 수 있었다.

\section{Apoptosis 유발 단백질의 발현에 미치는 EMCP의 영향}

이상의 결과들을 바탕으로 하여 $\mathrm{EMCP}$ 처리에 의한 apoptosis 유발 현상과 연관된 몇 가지 기본적인 기전 해석의 일환 으로 apoptosis 유발과 관련된 단백질의 발현을 Western blotting으로 확인해 보았다. Bax는 Bcl-2 family에 속하는 유전자 중, 대표적인 pro-apoptotic 유전자로 anti-apoptotic Bcl-2와 dimer를 이루고 있지만, Bax의 발현이 증가 또는 Bcl-2의 상대 적인 발현 감소는 mitochondria로부터 cytochrome $c$ 의 유리 를 촉진시켜 종양 억제 유전자인 p53, caspase 및 DNA 단편화 와 연관된 endonuclease 등의 활성을 증가시키는 것으로 알려 져 있다[15, 20]. Fig. 3에 나타낸 결과에서와 같이 대조군에 비하여 $\mathrm{EMCP}$ 처리군에서는 $\mathrm{Bax}$ 의 발현이 $\mathrm{EMCP}$ 농도 의존 적으로 현저하게 증가되었다. Caspase는 세포의 apoptosis 유 발에 핵심적인 역할을 하는 인자로서 불활성 상태로 세포내의 핵과 mitochondria의 외막에 존재하다가 apoptosis를 유도하 는 여러 자극에 의하여 활성화된다. 따라서 caspase의 활성화 는 apoptosis 유도에 대한 증거로써 많은 선행연구에서 검증 되어 왔으며 [4, 14], 본 실험에서 조사된 3가지의 caspase 단백 질의 비활성형 발현이 모두 현저하게 감소되어, $\mathrm{EMCP}$ 처리에 의해 그들의 활성이 증가되었음을 알 수 있었다. 또한 활성화 된 caspase-3의 대표적인 표적 단백질인 PARP 및 $\beta$-catenin의 단편화 및 발현 저하는 $\mathrm{EMCP}$ 처리에 의하여 caspase가 활성

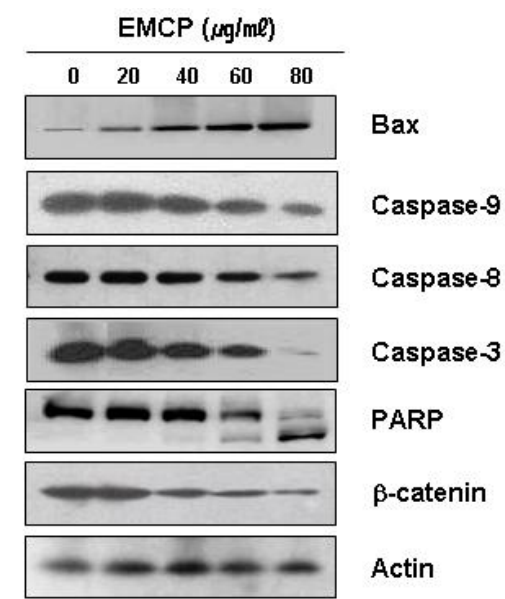

Fig. 3. EMCP treatment modulated expression of apoptosis-related proteins in U937 cells. Cells were incubated with the indicated concentrations of EMCP for $24 \mathrm{~h}$. The cells were lysed and then cellular proteins were separated by SDS-polyacrylamide gels. Separated proteins in gels transferred to nitrocellulose and probed with the indicated antibodies. Actin was used to ensure equal protein loading.

화되었을 것이라는 추측을 뒷받침하여 주는 결과이다.

\section{$\mathrm{EMCP}$ 처리에 의한 ROS 생성의 증가}

$\mathrm{EMCP}$ 의 처리에 의한 U937 세포의 apoptosis 유발에 ROS 생성과 연관성의 여부를 $\mathrm{H}_{2} \mathrm{DCFDA}$ probe를 이용하여 유세포 분석기로 조사하였다. $\mathrm{H}_{2} \mathrm{DCFDA}$ 는 형광 염색시약으로 세포 내의 esterase에 의해 DCFH로 가수분해되는데, DCFH는 ROS 가 존재하는 경우 $\mathrm{DCF}$ 로 산화되어 형광을 나타내므로 $\mathrm{ROS}$ 의 생성량은 $\mathrm{DCF}$ 의 발현량에 상응하는 것으로 생각할 수 있다 [9]. Fig. $4 \mathrm{~A}$ 에서 나타낸 바와 같이 ROS 생성은 $\mathrm{EMCP}$ 처리 후 30 분부터 증가하여 6 시간 후에는 약 10 배 이상 증가되었 으며, 이러한 ROS 생성의 증가가 ROS scavenger인 NAC의 전처리에 의하여 완벽하게 억제되었다(Fig. $4 \mathrm{~B})$. 따라서 $\mathrm{EMCP}$ 처리에 의한 ROS 생성이 apoptosis 유발에 직접적으로 관여하 는지를 조사한 결과, Fig. $5 \mathrm{~A}$ 에서 알 수 있듯이 $\mathrm{EMCP}$ 가 처리 된 세포에서 NAC의 전처리에 의하여 Sub-G1에 해당되는 세 포의 빈도가 유의적으로 감소되었으며, caspase-3의 표적 단백 질인 $\mathrm{PARP}$ 의 단편화 감소 및 pro-apoptotic 단백질인 $\mathrm{Bax}$ 의 발현 저하가 뚜렷하게 나타났다. 이상의 결과는 $\mathrm{EMCP}$ 에 의한 apoptosis 유발이 ROS 생성 의존적임을 보여주는 것이다.

EMCP 처리에 의한 $\mathrm{HO}-1$ 및 Nrf2의 발현과 ROS 생성 과의 연관성

$\mathrm{HO}$ 는 세포내의 heme의 양을 적절히 유지하도록 하는 중 요한 효소로 3 가지의 동형단백질로 존재한다. 대부분의 세포 에서 기본적인 대사활동에 관여하는 $\mathrm{HO}-2$ 및 $\mathrm{HO}-3$ 와는 다르 
A
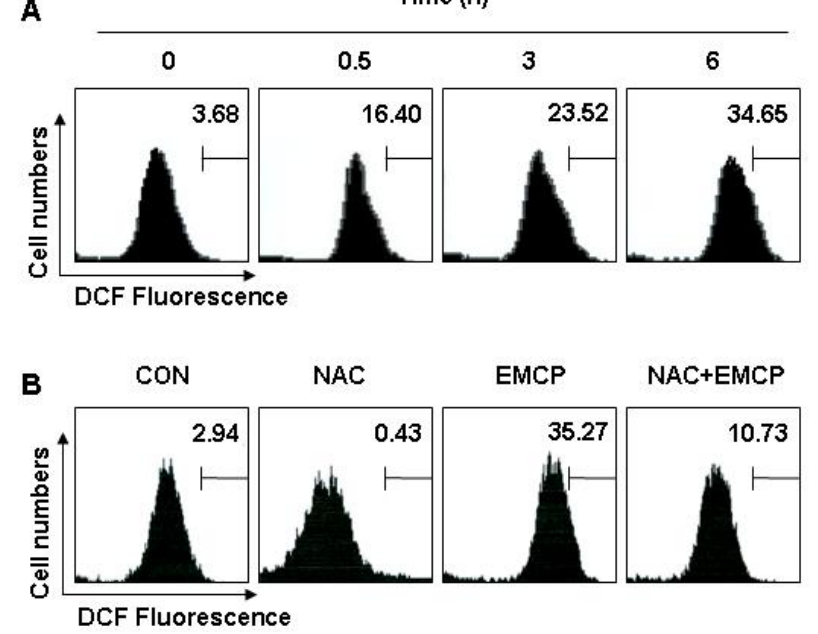

Fig. 4. EMCL treatment significantly increased intracellular ROS production in U937 cells. (A) U937 cells were seeded in a 6-well plate at an initial density of $3 \times 10^{5}$ cells per well. The cells were challenged with $80 \mu \mathrm{g} / \mathrm{ml}$ of EMCP for various periods. ROS levels were detected with flow cytometry using $\mathrm{H}_{2} \mathrm{DCFDA}$ probes. Bars represent DCF fluorescence intensities. (B) The cells were treated with NAC $(10 \mathrm{mM})$ for $1 \mathrm{~h}$ before challenge with $80 \mu \mathrm{g} / \mathrm{ml}$ for $6 \mathrm{~h}$. The data represent the average of two independent experiments.

A

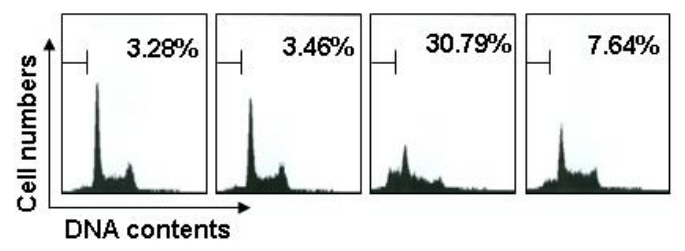

B CON NAC EMCP N+E

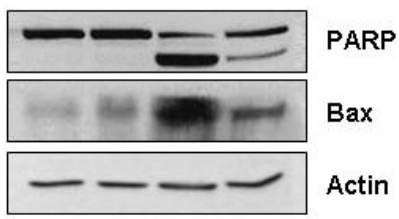

Fig. 5. The quenching of ROS generation inhibited EMCP-induced apoptosis in U937 cells. (A) The cells were treated with NAC $(10 \mathrm{mM})$ for $1 \mathrm{~h}$ before challenge with 80 $\mu \mathrm{g} / \mathrm{ml}$ for $24 \mathrm{~h}$. The percentage of the sub-G1 fraction of the cell cycle was examined by flow cytometry. (B) The cells grown under the same conditions as (A) were evaluated to check the expression of PARP and Bax. Actin was used to ensure equal protein loading.

게, HO-1은 산화적 스트레스, 지질다당류, 멜라토닌 및 아데노 신과 같은 다양한 자극에 의해 유도되는 형태이다[10, 12].
A

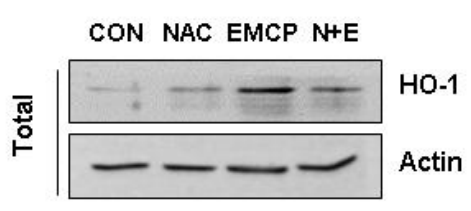

B CON NAC N+E EMCP

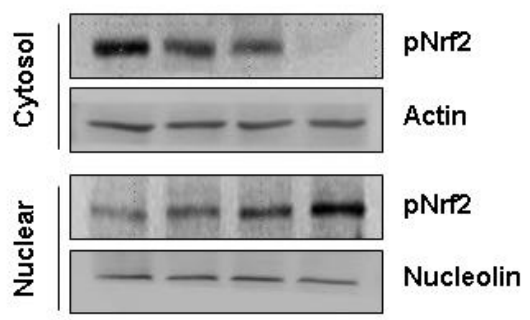

Fig. 6. EMCP increased the expression of HO-1 protein and translocation the pNrf2 into nucleus. (A) U937 cells were treated with EMCP for $24 \mathrm{~h}$ in the presence or absence of NAC. Immunoblotting was performed with the indicated antibodies. (B) Following treatment with the $\mathrm{EMCP}$, the cellular fraction (cytoplasm and nucleus) was isolated using an NE-PER ${ }^{\circledR}$ kit and the translocation of pNrf2 analyzed by Western blotting. Actin and nucleolin were used to ensure equal protein loading. The data represent three independent experiments.

$\mathrm{HO}-1$ 은 산화적 손상 억제, 염증 반응 감소 및 세포 증식 조절 을 통해 조직의 항상성 유지에 주용한 역할을 수행한다[6]. 따 라서 EMCP에 의한 U937 세포의 apoptosis 유발에서 HO-1의 역할을 조사하기 위하여 HO-1의 발현 정도를 Western blot 분석법으로 조사하였다. 그 결과 $\mathrm{EMCP}$ 가 처리한 세포에서 현저히 증가되었던 HO-1의 발현은 NAC의 전처리에 의해 $\mathrm{EMCP}$ 를 처리하지 않은 대조군과 비슷한 수준으로 감소되었 다(Fig. 6A). 또한 HO-1의 발현을 조절하는 전사인자인 Nrf2 의 세포질에서 핵으로의 이동을 조사한 결과, 인산화되어 핵 으로 이동하였던 $\mathrm{Nrf} 2$ 가 전처리한 $\mathrm{NAC}$ 에 의해 이동이 억제 되었다(Fig. 6B). 이상의 결과는 EMCP에 의한 apoptosis 유발 에는 ROS의 생성 증가가 깊이 관여되어 있으며, 이러한 산화 적 스트레스에 대응하기 위한 HO-1의 발현이 $\mathrm{pNrf2}$ 의 핵으로 의 이동에 의해 조절 받고 있음을 보여 주는 것이다.

\section{감사의 글}

이 논문은 정부(교육과학기술부)의 재원으로 한국연구재단 의 지원을 받아 수행된 기초연구사업임(2012046358).

\section{References}

1. Chang, H., Lin, H., Yi, L., Zhu, J., Zhou, Y., Mi, M. and Zhang, Q. 2010. 3,6-Dihydroxyflavone induces apoptosis in 
leukemia HL-60 cell via reactive oxygen species-mediated p38 MAPK/JNK pathway. Eur J Pharmacol 648, 31-38.

2. De Laurenzi, V. and Melino, G. 2000. Apoptosis. The little devil of death. Nature 406, 135-136.

3. Hengartner, M. O. 2000. The biochemistry of apoptosis. Nature 407, 770-776.

4. Henslev, P., Mishra, M. and Kyprianou, N. 2013. Targeting caspases in cancer therapeutics. Biol Chem 394, 331-343.

5. Jin, S. Y., Park, C., Jeong, J. W., Lee, J. D. and Choi, Y. H. 2007. Apoptotic cell death by water extract of Agaricus blazei Murill in human leukemia U937 cells. Cancer Prev Res 12, 98-105.

6. Jozkowicz, A., Was, H. and Dulak, J. 2007. Heme oxygenase-1 in tumors: is it a false frind? Antioxid Redox Signal 9, 2099-2117.

7. Jung, H. K., Jeong, Y. S., Park., C. D. Park, C. H. and Hong, J. H. 2010. Effect of the ethanol extract from Citrus peels on oxidative damage in alloxan-induced HIT-T15 cell. $J$ Korean Soc Food Sci Nutr 39, 1102-1106.

8. Jung, J. K., Son, K. H., Kim, Y. S. and Park, Y. K. 2011. Effect of Citri Pericarpium ethanol extract on collagen-induced arthritis in mice. Korean J Herbology 26, 1-6.

9. Kawiak, A., Zawacka-Pankau, J., Wasilewska, A., Stasilojc, G., Bigda, J. and Lojkowska, E. 2012. Induction of apoptosis in HL-60 cells through the ROS-mediated mitochondrial pathway by ramentaceone from Drosera aliciae. J Nat Prod 75, 9-14.

10. Min, K. J., Lee, J. T., Joe, E. H. and Kwon, T. K. 2011. An IкBa phosphorylation inhibitor induces heme oxygenase-1 (HO-1) expression through the activation of reactive oxygen species (ROS)-Nrf2-ARE signaling and ROS-PI3K/Akt signaling in an NF-kB-independent mechanism. Cell Signal 23, 1505-1513.

11. Park, E. J., Lim, J. H., Nam, S. I., Park, J. W. and Kwon, T. K. 2010. Rottlerin induces heme oxygenase-1 (HO-1) up-regulation through reactive oxygen species (ROS) de- pendent and PKC delta-independent pathway in human colon cancer HT29 cells. Biochimie 92, 110-115.

12. Pittalà, V., Salerno, L., Romeo, G., Modica, M. N., Siracusa, M. A. 2013. A focus on heme oxygenase-1 (HO-1) inhibitors. Curr Med Chem 20, 3711-3732.

13. Qin, K., Zheng, L., Cai, H., Cao, G., Lou, Y., Lu, T., Shu, Y., Zhou, W. and Cai, B. 2013. Characterization of chemical composition of Pericarpium Citri reticulatae volatile oil by comprehensive two-dimensional gas chromatography with high-resolution time-of-flight mass spectrometry. Evid Based Complement Alternat Med 2013, 237541.

14. Rahman, M. A., Kim, N. H. and Huh, S. O. 2013. Cytotoxic effect of gambogic acid on SH-SY5Y neuroblastoma cells is mediated by intrinsic caspase-dependent signaling pathway. Mol Cell Biochem 377, 187-196.

15. Ravi, A., Alvala, M., Sama, V., Kalle, A. M., Irlapati, V. K. and Reddy, B. M. 2012. Anticancer activity of Pupalia lappacea on chronic myeloid leukemia K562 cells. Daru 20, 86.

16. Shi, Q., Liu, Z., Yang, Y., Geng, P., Zhu, Y. Y., Zhang, Q., Bai, F. and Bai, G. 2009. Identification of anti-asthmatic compounds in Pericarpium citri reticulatae and evaluation of their synergistic effects. Acta Pharmacol Sin 30, 567-575.

17. Shin, Y. W. 2012. Changes in the anti allergic effect of Citrus unshii Pericarpium according to storage period. Korean $J$ Herbology 27, 37-44.

18. Wen, X., Lin, Z. Q., Liu, B. and Wei, Y. Q. 2012. Caspasemediated programmed cell death pathways as potential therapeutic targets in cancer. Cell Prolif 45, 217-224.

19. Yang, G., Lee, J., Jung, E. D., Ham, I. and Choi, H. Y. 2008. Lipid lowering activity of Citri unshii pericarpium in hyperlipemic rats. Immunopharmacol Immunotoxicol 30, 783-791.

20. Yu, F., Watts, R. N., Zhang, X. D., Borrow, J. M. and Hersey, P. 2006. Involvement of BH3-only proapoptotic proteins in mitochondrial-dependent phenoxodiol-induced apoptosis of human melanoma cells. Anticancer Drugs 17, 1151-1161. 


\section{초록 : 진피 메탄올 추출물의 활성산소종 생성을 통한 인체 백혈병 세포의 apoptosis 유발}

김가희 $^{1} \cdot$ 이문희 ${ }^{1,2} \cdot$ 한민호 $^{1,2} \cdot$ 박 철 $\cdot$ 홍수현 ${ }^{1 *} \cdot$ 최영현 ${ }^{1,2 *}$

( ${ }^{1}$ 동의대학교 한의과대학 생화학교실, ${ }^{2}$ 동의대학교 항노화연구소 및 블루바이오소재개발센터, ${ }^{3}$ 동의대학교 자연과학대학 분자생물학과)

진피(Citri Pericarpium)의 항암작용 기전 해석을 위하여 U937 백혈병 세포의 apoptosis 유발에 미치는 메탄올 추출물(EMCP)의 영향을 조사하였으며, apoptosis 조절에 중요한 몇 가지 유전자들의 발현 및 활성 변화, ROS의 생성 변화를 조사하였다. EMCP 처리에 의한 U937 세포의 증식 억제는 apoptosis 유도와 연관성이 있음을 DAPI 염색을 통한 apoptotic body 출현의 증가 및 Flow cytometry 분석에 의한 Sub-G1기 세포 빈도의 증가로 확인하 였다. $\mathrm{EMCP}$ 처리에 의한 apoptosis 유도에서 Bax 발현 증가, caspases의 활성 및 PARP의 단편화 등이 동반되었 으며, ROS 생성의 증가와 연관성이 있었다. 산화적 손상에 대해 세포나 조직을 보호하는 역할을 하는 것으로 알려진 세포 내 항산화 효소인 HO-1의 발현이 $\mathrm{EMCP}$ 의 처리에 의해 증가되었으나 ROS 생성 억제제인 NAC의 전처리에 의해 감소된 HO-1의 발현은 전사인자인 Nrf2의 핵으로의 이동 억제와 관련되어 있었다. 이상의 결과에 서 EMCP 처리에 의한 U937 세포의 apoptosis 유발에는 ROS 생성의 증가와 pNrf2에 의해 조절되는 HO-1의 발 현 증가가 중요한 기전으로 작용한다는 것을 알 수 있었다. 이러한 자료는 진피의 항암기전 해석을 이해하는데 중요한 기초자료로서 활용될 수 있을 것으로 생각된다. 